\title{
Developing a rehabilitation standard for landform stability for a uranium mine in northern Australia
}

\author{
JBC Lowry Department of the Environment and Energy, Australia \\ MJ Saynor Department of the Environment and Energy, Australia
}

\begin{abstract}
The rehabilitation works at the Ranger Uranium Mine (RUM) in the Northern Territory of Australia will be completed by 2026. As part of the process of mine closure and rehabilitation, the Supervising Scientist Branch of the Australian Government's Department of the Environment and Energy have developed a series of rehabilitation standards which will be applied to the mine site. Here, we describe the rehabilitation standard for landform stability, which will be used to assess the rehabilitated landform. This standard aims to promote the development of a stable landform that functionally merges with the surrounding landscape. To this end, the standard identifies two primary objectives. The first seeks to ensure that buried tailings are not exposed to the environment for a period of at least 10,000 years, while the second seeks to ensure that the erosion characteristics of the constructed landform approach those of comparable landforms in surrounding undisturbed areas. We describe the background and scientific basis to these objectives, and the measures prescribed to attain them. This includes the use of landform evolution modelling technologies and the development and application of monitoring tools and regimes to monitor the evolution of the landform over time. Finally, we describe how the development of this standard complements the development of an ecological restoration standard for the RUM. While the standards have been developed for a specific mine, we believe the principles developed may be applicable to existing and future mine rehabilitation activities elsewhere.
\end{abstract}

Keywords: rehabilitation standard, landform stability, erosion, modelling

\section{Introduction}

Uranium oxide has been produced at the Ranger Uranium Mine (RUM) in the Northern Territory of Australia since 1981 (Figure 1). However, mining of the open cut orebody ceased in 2012, with milling and production scheduled to cease by 2021 and the rehabilitation works to be completed by 2026 . Consequently, attention is now focussed on the closure and rehabilitation of the mine site. The unique location of the mine sitesurrounded by the World Heritage-listed Kakadu National Park, and upstream of floodplains and wetlands listed as 'Wetlands of International Significance' under the Ramsar convention-has meant that the development of closure criteria and rehabilitation plans for the mine has required special consideration. 


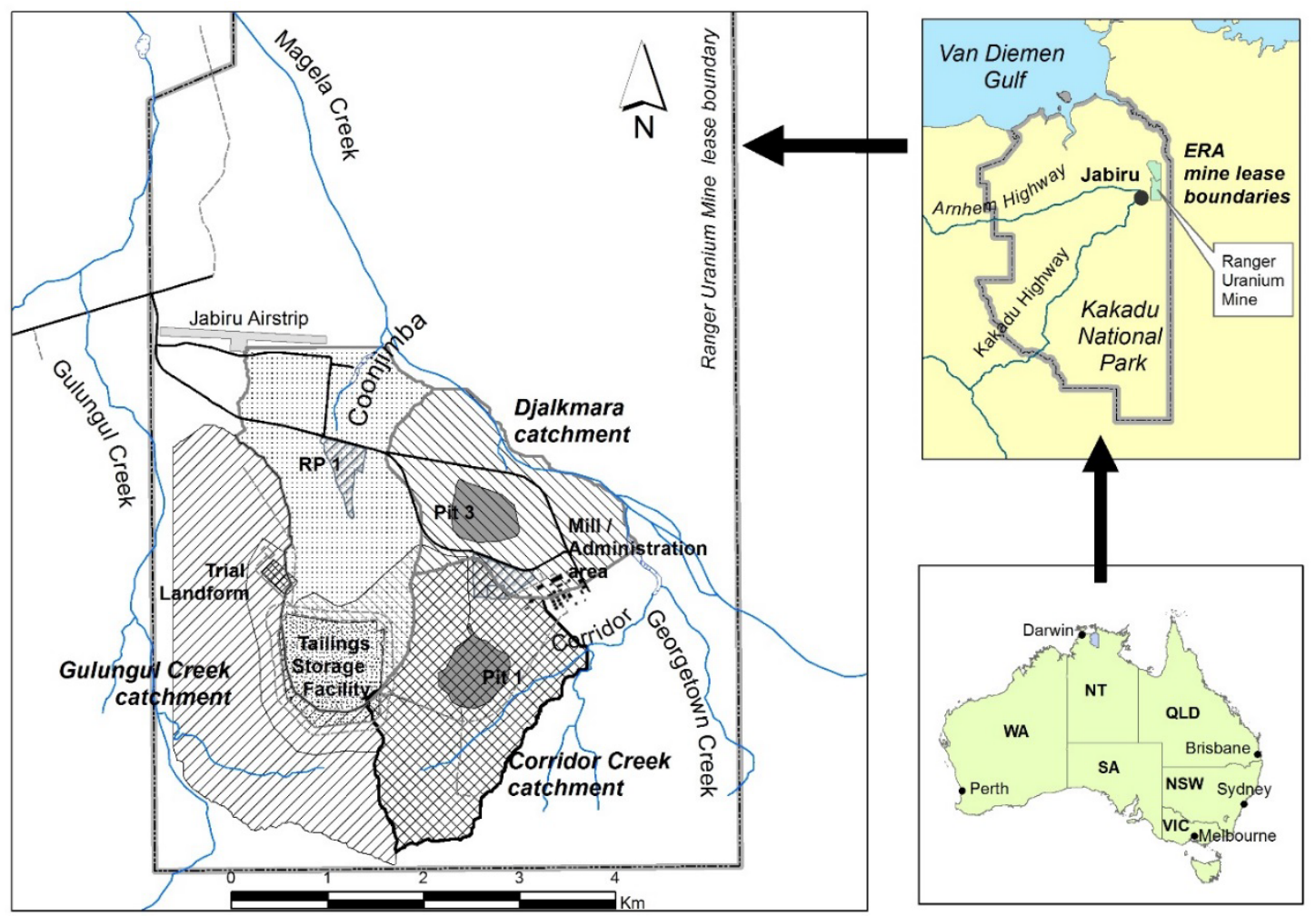

Figure 1 Location and layout of the Ranger Uranium Mine, Northern Territory

The Australian government, through the Supervising Scientist Branch (SSB) of the Department of the Environment and Energy, undertakes independent physical, chemical and biological monitoring programmes in the river catchments surrounding and enclosing the mine to ensure that the environment outside of the mine project area remains protected (Jones et al. 2009). More recently, the SSB has developed a series of rehabilitation standards for the RUM (Supervising Scientist Branch 2018). The rehabilitation standards quantify, based on the best available science, the specific values that will ensure a high level of environmental protection for the fauna, flora, landscapes and ecosystems of the rehabilitated site. The values can be used to assess the achievement of, or progress towards, the rehabilitation objectives, some of which may not be reached for a significant period of time.

Here, we focus on the rehabilitation standard for landform stability which incorporates the environmental requirements for the closure of the RUM and aims to ensure that the erosion characteristics of the rehabilitated landform, as far as can reasonably be achieved, do not vary significantly from those of comparable landforms in surrounding undisturbed areas and that erosion does not expose tailings for at least 10,000 years. This rehabilitation standard is consistent with the Queensland Government guideline, Rehabilitation Requirements for Mining Resource Activities (Department of Environment and Heritage Protection 2014).

Two key parameters were identified from the environmental requirements which formed the basis for development of the rehabilitation standard for landform stability: (1) the ability to ensure the isolation of mine tailings for a prescribed period of time; and (2) ensuring the erosion characteristics are similar to surrounding comparable landforms, thereby ensuring landform stability.

Consequently, the development of the standard has focussed on the identification and development of measures which can be used to assess the achievement of, or progress towards, the rehabilitation objectives. Importantly, it is recognised that some of these may not be reached for a significant period of time. Furthermore, an important element in developing the standard was incorporating the wishes of the Traditional Owners of the land. 
Each of the rehabilitation standards for the RUM have been developed in accordance with section $5 \mathrm{c}$ of the Environment Protection (Alligator Rivers Region) Act 1978 (Commonwealth of Australia 1978) and are advisory only.

\section{$2 \quad$ Objectives and measures for assessing and achieving landform stability}

The rehabilitation standard for landform stability (Supervising Scientist 2018) is defined through a set of parameters, objectives and measures which are summarised in Table 1 and described in the following sections. The net effect of these objectives and measures is intended to be a final landform with erosion characteristics comparable to landforms in surrounding undisturbed areas and with tailings physically isolated from the environment for at least 10,000 years.

Table 1 Rehabilitation standard for landform stability

\begin{tabular}{|c|c|c|}
\hline Parameter & Objective & Measure \\
\hline \multirow[t]{3}{*}{$\begin{array}{l}\text { Tailings } \\
\text { isolation }\end{array}$} & $\begin{array}{l}\text { Tailings will not be exposed by } \\
\text { erosion for } 10,000 \text { years. }\end{array}$ & $\begin{array}{l}\text { A high-resolution digital elevation model of the } \\
\text { constructed landform matches the approved } \\
\text { landform design, within applicable construction } \\
\text { standards. }\end{array}$ \\
\hline & & $\begin{array}{l}\text { Modelling of erosion on the constructed landform } \\
\text { matches results of erosion modelling conducted } \\
\text { on the approved landform design and confirms } \\
\text { tailings will not be exposed for } 10,000 \text { years. }\end{array}$ \\
\hline & & $\begin{array}{l}\text { Annual inspections show that there is no gully } \\
\text { formation occurring above the buried tailings. }\end{array}$ \\
\hline \multirow[t]{4}{*}{$\begin{array}{l}\text { Landform } \\
\text { stability }\end{array}$} & $\begin{array}{l}\text { Erosion characteristics of the } \\
\text { constructed landform are } \\
\text { approaching that of the surrounding } \\
\text { undisturbed landscape, including: }\end{array}$ & - \\
\hline & $\begin{array}{l}\text { - the denudation rate on the } \\
\text { landform will eventually approach } \\
\text { the regional background rate. }\end{array}$ & $\begin{array}{l}\text { Modelling of erosion on the constructed landform } \\
\text { predicts that the denudation rate will approach } \\
0.04 \mathrm{~mm} / \text { year. }\end{array}$ \\
\hline & $\begin{array}{l}\text { - total fine suspended sediment } \\
\text { concentrations in receiving water } \\
\text { downstream of the landform will } \\
\text { eventually approach background } \\
\text { concentrations. }\end{array}$ & $\begin{array}{l}\text { Event-based fine suspended sediment loads, } \\
\text { measured in Magela and Gulungul creeks at the } \\
\text { downstream boundary of the Ranger Project } \\
\text { Area, are approaching background values. }\end{array}$ \\
\hline & $\begin{array}{l}\text { - no bedload is transported away } \\
\text { from the constructed landform. }\end{array}$ & $\begin{array}{l}\text { Annual inspections show that no bedload is being } \\
\text { carried away from the constructed landform, in } \\
\text { the absence of active management. }\end{array}$ \\
\hline
\end{tabular}

\subsection{Tailings isolation}

At the RUM final storage of tailings will be in the mined out pits (Pit 1 and Pit 3) (Figure 1). Pit 1 has been filled with tailings and is currently being capped in preparation for rehabilitation. Tailings in the above-grade tailings storage facility (TSF) are being transferred into Pit 3 to enable the removal of the TSF. These tailings contain radionuclides with long half-lives and persistence in the environment (Schumm et al. 1984). 
A short-term measure of assessing tailings isolation, is to undertake regular monitoring of the landform to ensure that no gullies form across the pits or in areas where they could potentially expose tailings. However, the length of time for which tailings must be contained or isolated (10,000 years) has meant that the only realistic means of assessing long-term containment of tailings is through the use of landform evolution models (LEMs) to simulate erosion over extended periods of time. Specifically, erosion modelling is undertaken of a high-resolution digital elevation model of the as-constructed surface of the landform matching the approved landform design, within applicable construction standards for the simulated period of time required. The results of erosion modelling of the constructed landform may then be compared with those of the approved landform design, to assess the degree of erosion gullying.

\subsection{Landform stability}

To assess the degree to which erosion characteristics of the rehabilitated landform approach those of the surrounding undisturbed landscape, denudation of the final landform, or the rate of surface lowering, may be modelled and compared with denudation estimates for the natural surrounding landforms. Studies by Cull et al. (1992) identified a background denudation rate of $0.04 \mathrm{~mm} \pm 0.03 \mathrm{~mm} /$ year for the Magela catchment over a long period $(59,000 \pm 6,700$ years). This represents the best available estimate of the long-term erosion rate for the landscape surrounding the RUM site.

In addition to such modelling, measurement of the total fine suspended sediment concentrations in receiving water downstream of the landform may be used to assess rates that will eventually approach background concentrations. Complementing fine sediment transport, measurement of bedload transport may also be employed to ensure bedload is not transported away from the constructed landform.

\subsection{Measures for assessing tailings isolation and landform stability}

\subsubsection{Erosion modelling}

Landform evolution modelling provides a means of assessing the potential performance of constructed mine landforms. Over the last 40 years a variety of models have been used to assess erosion and simulate post mining landscape stability (Evans 2000; Loch et al. 2000). These models include the water erosion prediction program (WEPP) (Laflen et al. 1991), universal soil loss equation (USLE), modified universal soil loss equation (MUSLE), revised universal soil loss equation (RUSLE) (Onstad \& Foster 1975; Wischmeier \& Smith 1978; Renard et al. 1994), and SIBERIA (Willgoose et al. 1989). The CAESAR-Lisflood model (Coulthard et al. 2013) was originally developed to examine the effects of environmental change on river evolution, and to study the movement of contaminated river sediments. It has since been modified and applied to study the evolution of proposed rehabilitated mine landforms in northern Australia (Hancock et al. 2017; Lowry et al. 2014, 2016; Saynor et al. 2012).

Erosion on the Ranger rehabilitated landform has been modelled by the Supervising Scientist using the CAESAR-Lisflood and SIBERIA LEMs. Both erosion models have been calibrated using parameters collected and derived to best suit the specific local conditions of the final rehabilitated landform. These include the particle size distribution characteristics of waste rock on the mine site, and of the surrounding undisturbed landscape. In addition, synthetic rainfall datasets representing potential rainfall scenarios over 10,000 years have been developed specifically for the site (Verdon-Kidd \& Hancock 2016).

An important distinction between the models is that SIBERIA uses average annual rainfall while CAESARLisflood can model discrete rainfall events. This means that SIBERIA can simulate how a landscape may look on average, at a given time, while CAESAR-Lisflood can simulate the effects of specific, extreme rainfall events. Importantly, both models have been validated for local conditions. Application of the CAESARLisflood and SIBERIA models on a trial landform constructed at Ranger in late 2008 has demonstrated that model predictions of bedload yield and discharge correspond well with field measurements over a five to seven year period (Saynor et al. 2012; Lowry et al. 2014; Hancock et al. 2016c). Although the two models use different modelling techniques, the outputs of the models produce similar results. This provides confidence 
that the models can reliably predict rates of erosion and gully formation on a rehabilitated mine site (Hancock et al. 2010).

The CAESAR-Lisflood and SIBERIA erosion models have been independently reviewed and are consistent with world leading practice (Lowry et al. 2015a). The relevance and applicability of the models have been well documented in peer-reviewed journal articles (Evans et al. 1998, 2000; Evans 2000, Evans \& Willgoose 2000, Coulthard et al. 2012, Hancock et al. 2014, 2015, 2016a, 2016b, 2016c).

The predicted erosion rates of various landform designs for the Ranger site has been modelled using CAESARLisflood and SIBERIA, with the results provided to the mine operator, Energy Resources of Australia (ERA). Model simulations on early landform designs identified gullies with the potential to expose buried tailings over 10,000 years. Using this information, ERA has redesigned the landform to reduce the likelihood of gully formation over the buried tailings with modelling of these more recent landform designs confirming a reduction in erosion and gully formation (Lowry et al. 2009, 2013, 2015b). In particular, this recent modelling predicted that gullies that could expose buried tailings will not occur across the surface of Pit 1 within a simulated period of 1,000 years under an extreme wet rainfall scenario (Figure 2).


Figure 2 Modelled gully erosion to 1,000 years for Corridor Creek catchment (containing the Pit 1 landform). (a) cross-sectional transect (a)-(b) is shown across Pit 1 under; (b) an extreme dry; (c) an extreme wet rainfall scenario

Based on current modelling, the denudation rate on the landform is predicted to fall rapidly during the first 50 years post-construction and then decline gradually until approaching the regional background rate. This is predicted to take between hundreds to thousands of years, depending on the rainfall scenario modelled (Lowry et al. 2016). This trend is illustrated in the denudation rate for Corridor Creek, one of the four catchments that drains the landform, and which includes Pit 1, which has been capped and contains mineout tailings (Figure 3). 




Figure 3 Modelled denudation rate to 1,000 years for Corridor Creek with predicted rate to 10,000 years

Model simulations to date have involved multiple parameters, which have varied depending on the scenario modelled. While simulation results from the Ranger trial landform have given us confidence in the ability of the CAESAR-Lisflood model to predict outputs which match field observations, we recognise the need to address model uncertainty at greater spatial and temporal scales. Consequently, we have adopted the results of a sensitivity analysis of the CAESAR-Lisflood model (Skinner et al. 2018) which will enable us to better parameterise model simulations for a greater range of scenarios, including at different spatial and temporal scales, on an ongoing basis.

\subsubsection{Fine suspended sediment}

Fine suspended sediment is the fraction of the eroded sediment $<63 \mu \mathrm{m}$ in particle size. Fine suspended sediment is highly mobile and easily transported. In the absence of other disturbance in the region, increased levels of fine suspended sediment downstream of the mine can be attributed to erosion occurring on the landform.

As fine suspended sediment can be sourced from surface denudation or gully formation, it provides an overall measure of landform erosion characteristics. When fine suspended sediment concentrations downstream approach the natural background concentrations, it can be concluded that the erosion characteristics of the rehabilitated landform do not vary significantly from those of comparable landforms in the surrounding undisturbed areas. Turbidity may be used as a surrogate measure for fine suspended sediment where a sitespecific relationship has been developed (e.g. Moliere et al. 2005).

Moliere \& Evans (2010) identified significant regression relationships between the fine suspended sediment load transported during runoff events and the stream discharge during the respective events in the Alligator Rivers Region. They suggested that a regression method could be used with a paired Before-After-ControlImpact (BACIP) difference design (Stewart-Oaten et al. 1986, 1992; Humphrey et al. 1995) to assess the level of catchment disturbance based on fine suspended sediment loads measured during large runoff events.

The Moliere \& Evans (2010) method requires the measurement of fine suspended sediment and stream discharge upstream and downstream of the rehabilitated landform. The method is supported by Zapico et 
al. (2017), who concluded that it was a simple and reliable method to determine mining impacts on fine suspended sediment concentrations.

The erosion model should be periodically validated against observed fine suspended sediment concentrations and gully formation.

\subsubsection{Bedload}

Bedload is larger and heavier than fine suspended sediment and does not travel as far in surface water. Bedload settles out as the angle of the slope decreases and flow velocities reduce, and so sedimentation basins are usually effective for managing bedload transport. However, bedload can potentially move along drainage channels during high flow events if the basins are not designed appropriately. Erosion plot studies on the RUM trial landform demonstrated that bedload transport declined exponentially with time after landform construction (Saynor \& Erskine 2016). While these results show that bedload movement should not represent a long-term risk, the impact of bedload to downstream ecosystems could be substantial if it is not managed (Humphrey et al. 2016).

\section{Aspirations of Traditional Owners}

Understanding and incorporating the wishes of the Traditional Owners of the land over which the mine site is located is an important element of RUM site rehabilitation. With respect to the long-term stability of the landform, the Mirrar Traditional Owners have expressed the desire that erosion on the rehabilitated landform is minimised (Garde 2015). They have also articulated the following cultural objectives (Garde 2015):

1. The topography of the landform blends in, as much as practical, with the surrounding environment. This will allow a visual connection with key cultural sites to be re-established.

2. The number of major water bodies present on the final landform does not exceed the number of water bodies in the same location before mining commenced.

3. The landform is able to be accessed and is readily traversable by people on foot.

Importantly, the surface texture of the rehabilitated landform, which will affect the ability to traverse or walk across the landform, is not subject to a rehabilitation standard. This has been addressed in the cultural closure criteria negotiated directly between the Mirrar Traditional Owners and the mine operator, ERA.

\section{$4 \quad$ Links to other rehabilitation standards}

Nine rehabilitation standards have been developed by the SSB specifically for the RUM. These fit broadly into the themes of radiation, water and sediment, ecosystem restoration, soil, culture and landform. The themes are linked, not just through the specific geographic area to which they are applied (the RUM lease) but through the integration of the rehabilitation outcomes. For example, the rehabilitation standards relating to water and sediment quality recognise the need for a stable landform that does not generate sediment or turbidity levels that could impact adversely on aquatic ecosystem health downstream of the mine site. Similarly, the rehabilitation standard for ecological restoration recognises that the target of a fully restored ecosystem that is similar to the surrounding area will take many decades, and will require a stable, noneroding landform on which to grow. Similarly, the presence of a growing healthy vegetation community will assist with minimising gully formation and enhance landform stability.

\section{Conclusions and recommendations}

The Supervising Scientist has developed a series of rehabilitation standards against which the success of rehabilitation can be measured. 
The standards are based on 40 years of research and monitoring that provide an evidence-based quantification of the Environmental Requirements. They are not mandatory but will form the basis of the SSB advice on the closure criteria and rehabilitation plans proposed by the mine operator, ERA, as well as the eventual success of rehabilitation.

When viewed by itself, this standard will provide the means for assessing the long-term geomorphic stability of a rehabilitated landform. When viewed with the other related standards, they provide the basis for ensuring the environment of the RUM is successfully rehabilitated.

Rehabilitation planning can only be based on the best available information at a given time, but this should not preclude the continual improvement of the knowledge base and its subsequent application where directly relevant and possible. The SSB recognises the need for ongoing research into stability of the rehabilitated landform and has identified additional knowledge required to ensure appropriate management of the key risks to the environment from the rehabilitation of the RUM site into the future. For landform stability, these key knowledge needs reflect the need to better understand the background rate of sediment movement and formation in the surrounding region, and updating landform and model parameters as additional information becomes available through ongoing and proposed monitoring and modelling activities. These key knowledge needs are shown in Table 2, with each need and its related questions prefixed with the identifier LAN, to indicate that they relate to the landform stability theme. The prefixes are used here simply to identify and distinguish the different key knowledge needs and questions of the different rehabilitation themes and standards applied to the rehabilitation of the RUM.

Table 2 Key knowledge needs for landform stability (Supervising Scientist Branch 2018)

\begin{tabular}{ll}
\hline Key knowledge needs & Questions \\
\hline $\begin{array}{l}\text { LAN1. Determining baseline erosion } \\
\text { and sediment transport characteristics } \\
\text { in areas surrounding the Ranger }\end{array}$ & $\begin{array}{l}\text { LAN1A. What is the baseline rate of gully formation for areas } \\
\text { suroject Area (RPA). }\end{array}$ \\
$\begin{array}{ll}\text { LAN1B. What is the baseline rate of bedload movement and } \\
\text { deposition in creeks and billabongs? }\end{array}$ \\
$\begin{array}{ll}\text { LAN3. Predicting erosion of the } \\
\text { rehabilitated landform. }\end{array}$ \\
$\begin{array}{l}\text { LAN3A. What is the optimal landform shape and surface } \\
\text { erosion? }\end{array}$ \\
$\begin{array}{l}\text { LAN3C. How can we optimise the landform evolution model to } \\
\text { predict the erosion characteristics of the final landform } \\
\text { (e.g. refining parameters, validation using bedload, suspended } \\
\text { sediment and erosion measurements, quantification of } \\
\text { uncertainty and modelling scenarios)? }\end{array}$ \\
\hline
\end{tabular}

Until it can be determined that rehabilitation objectives have or will be reached, there will be an ongoing need to ensure environmental protection during and after rehabilitation, through continued erosion and water quality monitoring, including the comparison of water quality data with relevant water quality limits.

While the objectives and measures for rehabilitation have been developed specifically for the RUM, we believe that the methods and objectives may be adapted and applied to other mines sites which are due to be rehabilitated.

\section{Acknowledgements}

The authors thank Dr Chris Humphrey and Dr Renee Bartolo who constructively commented on a draft of this paper. 


\section{References}

Commonwealth of Australia 1978, Environment Protection (Alligator Rivers Region) Act 1978.

Coulthard, T, Hancock, GR \& Lowry, J 2012, 'Modelling soil erosion with a downscaled landscape evolution model', Earth Surface Processes and Landforms, vol. 37, pp. 1046-1055.

Coulthard, TJ, Neal, JC, Bate, PD, Ramirez J, de Almeida, GAM \& Hancock, GR 2013, 'Integrating the LISFLOOD-FP 2D hydrodynamic model with the CAESAR model: Implications for modelling landscape evolution', Earth Surface Processes and Landforms, vol. 38, issue 15, pp. 1897-1906, DOI: 10.1002/esp.3478

Cull, RF, Hancock, G, Johnston, A, Martin, P, Martin, R, Murray, AS, ...\& Wasson, RJ 1992, 'Past, present and future sedimentation on the Magela plain and in its catchment', in RJ Wasson (ed.), Modern sedimentation and late Quaternary evolution of the Magela plain, Research Report 6, Supervising Scientist for the Alligator Rivers Region, Canberra, pp. 226-268.

Department of Environment and Heritage Protection 2014, Rehabilitation requirements for mining resource activities. Report EM1122, ESR/2016/1875, Version 2, Brisbane.

Evans, KG 2000, 'Methods for assessing mine site rehabilitation design for erosion impact', Australian Journal of Soil Research, vol. 38, issue 2, pp. 231-248.

Evans, KG \& Willgoose, GR 2000, 'Post-mining landform evolution modelling. II. Effects of vegetation and surface ripping', Earth Surface Processes and Landforms, vol. 25, issue 8, pp. 803-823.

Evans, KG, Willgoose, GR, Saynor, MJ \& House, T 1998, Effect of vegetation and surface amelioration on simulated landform evolution of the post-mining landscape at ERA Ranger Mine, Northern Territory, Supervising Scientist Report 134, Canberra.

Evans, K, Saynor, M, Willgoose G, \& Riley, SJ 2000, 'Post-mining landform evolution modelling. I. Derivation of sediment transport model and rainfall-runoff model parameters', Earth Surface Processes and Landforms, vol. 25, issue 7, pp.743-763.

Garde, M 2015, Closure Criteria Development-Cultural, Darwin.

Hancock, GR, Lowry, JBC, Coulthard, TJ, Evans, KG \& Moliere, DR 2010, 'A catchment scale evaluation of the SIBERIA and CAESAR landscape evolution models', Earth Surface Processes and Landforms, vol. 35, pp. 863-875.

Hancock, GR, Willgoose, GR \& Lowry, J 2014, 'Transient landscapes: gully development and evolution using a landscape evolution model', Stochastic Environmental Research and Risk Assessment, vol. 28, issue 1, pp. 83-98, doi: 10.1007/s00477-013-0741-y

Hancock, GR, Lowry, J \& Coulthard, T 2015, 'Catchment reconstruction - erosional stability at millennial time scales using landscape evolution models', Geomorphology, vol. 231, pp. 15-27.

Hancock, GR, Lowry, JBC \& Coulthard, TJ 2016a, 'Long-term landscape trajectory - can we make predictions about landscape form and function for post-mining landforms', Geomorphology, vol. 266, pp. 121-132.

Hancock, GR, Coulthard, TJ \& Lowry, JBC 2016b, 'Predicting uncertainty in sediment transport and landscape evolution - the influence of initial surface conditions', Computers and Geosciences, vol. 90, pp. 117-130.

Hancock, GR, Lowry, JBC \& Saynor, MJ 2016c, 'Early landscape evolution - a field and modelling assessment for a post-mining landform', Catena, vol.147, pp. 699-708.

Hancock, GR, Verdon-Kidd, D \& Lowry, JBC 2017, 'Soil erosion predictions from a landscape evolution model - An assessment of a post-mining landform using spatial climate change analogues', Science of the Total Environment, vol.601-602, pp. 109-121.

Humphrey, CL, Faith, DP \& Dostine, PL 1995, 'Base-line requirements for assessment of mining impact using biological monitoring', Australian Journal of Ecology, vol. 20, pp. 150-166.

Humphrey, CL, Bishop, KA \& Dostine, PL 2016, 'Vulnerability of fish and macroinvertebrates to key threats in streams of the Kakadu region, northern Australia: assemblage dynamics, existing assessments and knowledge needs', Marine and Freshwater Research, vol. 69, pp. 1092-1109, doi: 10.1071/MF16175

Jones, DR, Humphrey, C, van Dam, R, Harford, A, Turner, K \& Bollhoefer, A 2009, 'Integrated chemical, radiological and biological monitoring for an Australian uranium mine - a best practice case study', Proceedings International Mine Water Conference, Pretoria, pp. 95-104.

Laflen, JM, Elliot, WJ, Simanton, JR, Holzhey, CS \& Kohl, KD 1991, 'WEPP soil erodibility experiments for rangeland and cropland soils', Journal of Soil and Water Conservation, pp. 39-34.

Loch, RJ, Connolly, RD \& Littleboy, M 2000, 'Using rainfall simulation to guide planning and management of rehabilitated areas: Part 2, Computer simulations using parameters from rainfall simulation', Land Degradation and Development, vol. 11, issue 3, pp. 241-255.

Lowry, J, Evans, K, Coulthard, T, Hancock, G \& Moliere, D 2009, 'Assessing the impact if extreme rainfall events on the geomorphic stability of a conceptual rehabilitated landform in the Northern Territory of Australia', in A Fourie \& M Tibbett (eds), Proceedings of the Fourth International Conference on Mine Closure, Australian Centre for Geomechanics, Perth, pp. 203-212.

Lowry, J, Coulthard, T \& Hancock, G 2013, 'Assessing the long-term geomorphic stability of a rehabilitated landform using the CAESARLisflood landscape evolution model', in M Tibbett, AB Fourie \& C Digby (eds), Proceedings of the Eighth International Conference on Mine Closure, Australian Centre for Geomechanics, Perth, pp. 611-624.

Lowry, J, Saynor, M, Erskine, W, Coulthard, T \& Hancock, G 2014, 'A multi-year assessment of landform evolution predictions for a trial rehabilitated landform', Proceedings of the Life-of-Mine 2014 Conference, Australasian Institute of Mining and Metallurgy, Melbourne, pp. 67-80.

Lowry, J, Erskine, W, Pickup, G, Coulthard, T \& Hancock, G 2015a, Future Directions for Application of Landform Modelling by the Supervising Scientist: Response to the Review of the application of the CAESAR-Lisflood model by the eriss Hydrologic, Geomorphic and Chemical Processes program, Supervising Scientist Report 210, Supervising Scientist, Darwin. 
Lowry, J, Hancock, G \& Coulthard, T 2015b, 'Assessing the evolution of a post-mining landscape using landform evolution models at millennial time scales', in A Fourie, M Tibbett, L Sawatsky \& D van Zyl (eds), Proceedings of the 10th International Conference on Mine Closure, InfoMine, Vancouver, pp. 207-220.

Lowry, JBC, Verdon-Kidd, D, Hancock, GR, Saynor, MJ \& Coulthard, TJ 2016, 'Application of synthetic rainfall data to long-term modelling of a rehabilitated landform', Proceedings of the Life-of-Mine 2016 Conference, Australasian Institute of Mining and Metallurgy, Melbourne, pp. 75-79.

Moliere, DR \& Evans, KG 2010. 'Development of trigger levels to assess catchment disturbance on stream suspended sediment loads in the Magela Creek, Northern Territory, Australia', Geographical Research, doi: 10.1111/j.1745-5871.2010.00641.x

Moliere, DR, Saynor, MJ \& Evans, KG 2005, 'Suspended sediment concentration-turbidity relationships for Ngarradj - a seasonal stream in the wet-dry tropics' Australian Journal of Water Resources, vol. 9, pp. 37-48.

Onstad, CA \& Foster, GR 1975, 'Erosion modelling on a watershed', Transactions of the American Society of Agricultural Engineers, vol. 26, pp. 1102-1104.

Renard, KG, Laflen, JM, Foster, GR \& McCool, DK 1994, 'The revised universal soil loss equation', in R Lal (ed.), Soil Erosion Research Methods, Soil and Water Conservation Society, Ankeny, 2nd edn, pp. 105-124.

Saynor, MJ \& Erskine, WD 2016, 'Bed Load losses from Experimental Plots on a Rehabilitated Uranium Mine in Northern Australia', Proceedings of the Life-of-Mine 2016 Conference, Australasian Institute of Mining and Metallurgy, Melbourne.

Saynor, MJ, Lowry, J, Erskine, WD, Coulthard, T, Hancock, G, Jones, D \& Lu, P 2012, 'Assessing erosion and run-off performance of a trial rehabilitated mining landform', Proceedings of the Life-of-Mine 2012, Brisbane, Australasian Institute of Mining and Metallurgy, Melbourne.

Schumm, SA, Costa, JE, Toy, TJ, Knox, JC \& Warner, RF 1984, 'Geomorphic hazards and uranium tailings disposal', Management of Wastes from Uranium Mining and Milling, International Atomic Energy Agency, Vienna, pp. 111-124.

Skinner, CJ, Coulthard, TJ, Schwanghart, W, Van De Wiel, M \& Hancock, G 2018, 'Global sensitivity analysis of parameter uncertainty in landscape evolution models', Geoscientific Model Development, vol. 11, pp.4873-4888.

Stewart-Oaten, A, Murdoch, WW \& Parker, KR 1986, 'Environmental impact assessment: 'Pseudoreplication' in time?', Ecology, vol. 67, pp. 929-940.

Stewart-Oaten, A, Bence, JR \& Osenberg, CW 1992, 'Assessing effects of unreplicated perturbations: no simple solutions', Ecology, vol. 73, pp. 1396-1404.

Supervising Scientist Branch 2018, Landform Stability - Rehabilitation Standard for the Ranger uranium mine (version 1), Supervising Darwin, viewed 14 December 2018, http://www.environment.gov.au/science/supervising-scientist/publications/ssrehabilitation-standards

Verdon-Kidd, D \& Hancock, G 2016, Development of synthetic rainfall datasets to enable long-term landform modelling for periods of up to 10,000 years in the Alligator River Region, University of Newcastle, Callaghan.

Willgoose, GR, Bras, RL \& Rodriguez-Iturbe, I 1989, A physically based channel network and catchment evolution model, TR 322, Massachusetts Institute of Technology, Boston.

Wischmeier, WH \& Smith, DD 1978, Predicting rainfall erosion losses - a guide to conservation planning, Agriculture Handbook No. 537.2, United States Department of Agriculture.

Zapico, I, Laronne, JB, Martin-Moreno, C, Martin-Duque, JF, Ortega, A \& Sanchez-Castillo, L 2017, 'Baseline to evaluate off-site suspended sediment-related mining effects in the Alto Tajo Natural Park, Spain', Land Degradation \& Development, vol. 28, pp. 232-242.



http://creativecommons.org/licenses/by/3.0/au/

Developing a rehabilitation standard for landform stability for a uranium mine in northern Australia, (C) Commonwealth of Australia (Department of the Environment and Energy) 2019 